\title{
THE EFFECT OF AIR QUALITY DUE TO HOUSEHOLD WASTE SEWERS ON THE GROWTH OF CAYENNE PEPPER (Capsicum frustescens $\mathbf{L}$.)
}

\author{
Suhendra Iskandar \\ Ibtidaiyah Teacher Training Program (PGMI), IAIN Sultan Amai Gorontalo, Gorontalo, Indonesia \\ Email: suhendra_iskandar@iaingorontalo.ac.id
}

Accepted: January 04, 2022. Approved: January 14, 2022. Published: January 17, 2022

\begin{abstract}
Research has been carried out on the effect of air pollution due to household sewage on the growth of cayenne pepper (Capsicum frustescens L.). A total of 12 samples were divided into 4 groups: 3 samples in the group placing planting locations near the sewers, 3 samples in the group placing planting locations near the sewers and giving liquid NPK fertilizer once a day, 3 samples in the group placing planting locations in places with high-quality clean air, and 3 samples in the planting location group in places with clean air quality and application of liquid NPK fertilizer once a day. The sample growth was observed for 90 days to see the difference in growth in each sample group. It was found that the samples in the group placing the planting location near the sewer, both those who were given and those who were not given liquid NPK fertilizer once a day, showed severe shrinkage symptoms in 13-14 days after planting. The samples placed in a place with clean air quality without liquid NPK fertilizer showed growth disorders in the 60 days after planting. Meanwhile, samples placed in a place with clean air quality and given liquid NPK fertilizer once a day showed fertile growth.
\end{abstract}

Keywords: Air Quality, Sewer Waste, Plant Growth

\section{INTRODUCTION}

Agriculture is the activity of managing living natural resources with the help of technology, capital, labor, and management to produce agricultural commodities in an agroecosystem [1-3]. Several aspects must be considered in growing crops so that agricultural yields can be optimal, not only in selecting agricultural land and fertilization, but air quality also has an essential role in the success of a farming business.

Plant maintenance is carried out mainly by land maintenance. Land maintenance can be done either by maintaining soil quality by fertilizing or by structuring the vegetation that grows on it [4-5]. Plant maintenance that is no less important is plant protection. Plant protection can be done by giving pesticides to prevent pest attacks, giving fungicides to prevent fungal attacks, and so on. However, no less important is protection against unhealthy air.

Plants contaminated with motor vehicle pollutants tend to be unhealthy and show disturbances in the photosynthetic and metabolic systems [6-7]. Pollutant gases from transportation activities were able to cause macroscopic (chlorosis/necrosis) and microscopic (tissue damage/abnormalities) damage to leaves, which was mainly due to the $\mathrm{Pb}$ content in the air pollutant [8-9].

The same applies to household sewage. Not only is wastewater itself toxic because it contains various types of toxic pollutants from human waste, but the smell of wastewater is also toxic. This sewer smell at least contains ammonia gas which is corrosive and toxic even at low levels.
This research was conducted to see whether there was a significant difference in growth between plants grown in areas exposed to and not exposed to household sewerage air. Cayenne pepper plants are almost planted in all parts of Indonesia, do not have a specific planting time, and do not have certain growing requirements. It is what underlies the selection of cayenne pepper as a sample in this research.

\section{RESEARCH METHODS}

This research was conducted by planting cayenne pepper seeds in four different conditions. Each group consisted of three samples (each sample was in a separate pot where five seeds were planted in each pool, and the first one that grew was considered the sample, while if there was one that grew later, it was eliminated). The first group of samples is labeled A1, A2, and A3. These samples were placed in a location with poor air quality that was directly exposed to the smell of household sewage. The second group of samples labeled as B1, B2, and B3 was also placed in a location with the same conditions as the first group but accompanied by control of Patek disease by giving Extra Green liquid NPK fertilizer once a day, in the morning. The third group of samples labeled as $\mathrm{C} 1, \mathrm{C} 2$, and $\mathrm{C} 3$ was placed in a location with pristine air quality (not exposed to sewer smell or other unpleasant odors). The fourth group of samples labeled as D1, D2, and D3 was placed in the same conditions as the third group but accompanied by control of Patek disease by administering liquid NPK fertilizer with Extra Green brand once a day morning. Patek disease control is carried out to control the effect of 
variations caused by Patek disease that often appears in cayenne pepper plants. Each group was given the same treatment about soil conditions where soil that was explicitly for agriculture was purchased at the Hulondani Farm Shop in Gorontalo City. After that, the growth of each sample of cayenne pepper was observed for three months.

\section{RESULTS AND DISCUSSION}

Air pollution is the addition of certain physical or chemical materials or substrates into the normal air environment that reaches a certain amount so that it can be detected by humans and can affect humans, vegetation, and materials [10].

This research was carried out by placing the samples in two different conditions, and one was placed in a place that was not exposed to sewer waste air, while the other was placed in a location exposed to sewer waste air. Each condition was further divided into two treatments, and one was given control of Patek disease by administering liquid NPK fertilizer with Extra Green brand. It distinguishes illnesses caused by exposure to waste air from illnesses caused by pests and viruses such as Patek [11]. Each treatment group was given the same soil conditions, namely particular soil purchased at the Hulondani Gorontalo Agricultural Store, so variables did not appear due to soil fertility conditions.

One of the primary pollutants from household waste sewer air is ammonia gas which can come from human urine or washing water. In the form of a gas, ammonia is very light, lighter than oxygen in the lower atmosphere so that it can rise, but heavier than carbon dioxide so that it stays at the bottom [12]. Ammonia is hazardous because of its irritating and corrosive properties [13].

Although ammonia contributes to plant nutrition, it is an acidic compound and can damage plant leaves [14]. Plants can only absorb ammonia as a nutrient if it is bound to groundwater [15]. However, it must be remembered that if there is too much $\mathrm{N}$ in the water, the $\mathrm{pH}$ of the water will be low, which can kill plants [16].

Air pollution, especially ammonia, causes damage to plant leaves. Air pollutants' injury in the leaf mesophyll will significantly impact photosynthetic activities [17-18]. It will disrupt plant metabolic processes that require energy from photosynthesis. It will further reduce the plant's immunity to various diseases [19].

The twelve research samples of cayenne pepper germinated between 7-8 days after planting (DAP). Samples in the first and second groups began to show symptoms of growth disorders between the ranges of 13-14 DAP. Symptoms include severe shrinking, yellowing, wilting of the leaves and slow plant height growth. It happened to all samples placed in places exposed to sewer air, including samples that had been given liquid NPK fertilizer. It indicates that the leading cause of growth disturbances is most likely due to the influence of sewer air that contaminates the two sample groups, which mainly comes from ammonia gas which can corrode plant leaves with the characteristics of severely faded, wilted, yellowing plant leaves, which are in accordance with the symptoms indicated by the two sample groups.

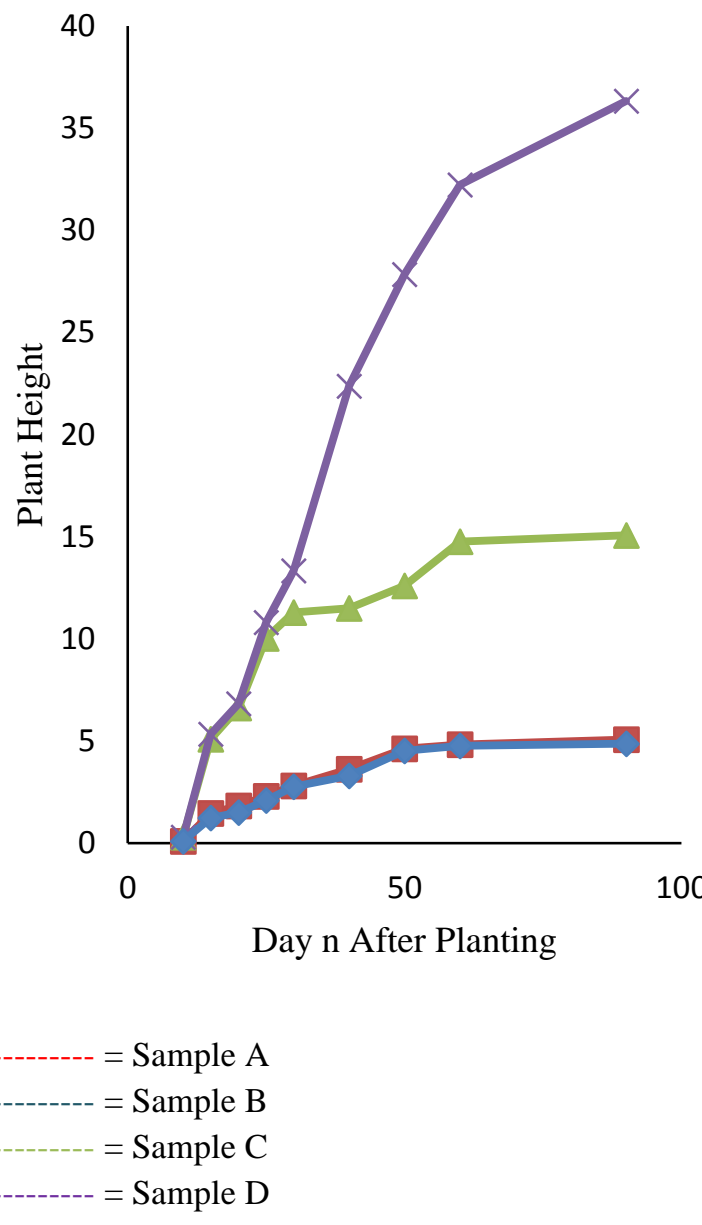

Figure 1. Average Plant Height of Cayenne Pepper at a Certain Time

On the 60th day, all samples in the third group began to show symptoms of growth disorders with the characteristics of yellowing and wilting of leaves accompanied by white powder on the underside of the leaves. The symptoms shown are different from those indicated by Samples A and B, who were exposed to sewer air which showed symptoms of severe leaf shriveling. Researchers suspect that Pests or viruses might attack sample C. The application of NPK liquid fertilizer effectively increases plant resistance to pests and viruses where only sample D was given this NPK liquid fertilizer while Sample C was not [20-24]. The difference in growth between Sample $\mathrm{C}$ and Sample D was already visible on the 30th day. Researchers suspect this is due to malnutrition 
because Sample C was not given additional nutrients like Sample D after planting.

The samples in the fourth group, until the day when this research ended, on the 90th day, all samples grew well and fertile which had plant heights in the range of $31.0-40.0 \mathrm{~cm}$. The samples in the first group had plant heights of $4.7-5.1 \mathrm{~cm}$. Samples in the second group had plant heights of $4.8-5.3 \mathrm{~cm}$, and samples in the third group had $13.7-16.1 \mathrm{~cm}$. Finally, the samples in the first, second, and third groups were still alive in this research but poor condition.

\section{CONCLUSION}

Based on this research, it was concluded that air quality affects plant growth where sewer air containing ammonia gas can inhibit plant growth. It can be helpful for student learning in the implementation in the environment around the residence. The research results can also be used as guidelines for activities in the biology laboratory in student practicum activities.

\section{REFERENCES}

[1] Pemerintah Republik Indonesia, UndangUndang Nomor 19 Tahun 2013.

[2] Alam, G. M., \& Shrestha, R. B. (2021). Promote Sustainability of Family Farming for Climate-Resilient Food Systems in South Asia. Regional Action Plan to Implement the UNDFF for Achieving the SDGs in South Asia, 175.

[3] Prakash, N., Roy, S. S., Ansari, M. A., \& Sharma, S. K. (2015). A comprehensive manual on integrated farming system: An approach towards livelihood security and natural resource conservation. Publication No. $R C M(T M), 8,368$.

[4] Suwarto (2008). Produktifitas Lahan dan Biaya Usaha Tani Tanaman Pangan di Kabupaten Gunung Kidul, Jurnal Ekonomi Pembangunan 9. No. 2. Hal $168-183$.

[5] Panjaitan, S. (2016). Pengaruh Pemeliharaan terhadap Pertumbuhan Tanaman dan Permudaan Alam dalam Sistem Silvikultur Tebang Rumpang. Jurnal Penelitian Ekosistem Dipterokarpa 2. No. 1. Hal $41-48$.

[6] Anisa, S. (2019). Pengaruh Pencemaran Udara terhadap Kerapatan Stomata pada Daun Mahoni (Swietenia mahagoni L. Jacq) sebagai Tanaman Pelindung di Bandar Lampung. Skripsi. Lampung: Fakultas Tarbiyah dan Keguruan Universitas Islam Negeri Raden Intan.

[7] Rives, C., Fougerat, A., Ellero-Simatos, S., Loiseau, N., Guillou, H., Gamet-Payrastre, L., \& Wahli, W. (2020). Oxidative stress in NAFLD: Role of nutrients and food contaminants. Biomolecules, 10(12), 1702.
[8] Rachmani, N. dan Hadi W. (2003). Dampak Pencemaran Udara terhadap Tumbuhan di Kebun Bibit Bratang Surabaya. Jurnal Purifikasi 4. No. 2. Hal. 55 - 60.

[9] Huang, D., Tao, J., Cheng, M., Deng, R., Chen, S., Yin, L., \& Li, R. (2020). Microplastics and nanoplastics in the environment: Macroscopic transport and effects on creatures. Journal of hazardous materials, 124399.

[10]Fardiaz, S. (1992). Polusi Air dan Udara. Yogyakarta: Kanisius.

[11] Harjanti, W.S. dkk. (2016). Analisis Risiko Kesehatan Lingkungan Pajanan Gas Amonia $\left(\mathrm{NH}_{3}\right)$ pada Pemulung di TPA Jatibarang, Semarang. Jurnal Kesehatan Masyarakat 4. No. 3. Hal. $921-930$.

[12] Imelda, H. (2007). Analisa Dampak Gas Amoniak dan Klorin pada Paru Pekerja Pabrik Sarung Tangan ' $\mathrm{X}$ ' Medan. Tesis. Medan: Program Studi S2 Ilmu Kesehatan Masyarakat Universitas Sumatera Utara.

[13]BPOM RI (2011). Manajemen Risiko. Jakarta: Direktorat Pengawasan Produk dan Bahan Berbahaya.

[14] Agustia, D. (2011). Pengaruh Lama Penyimpanan Urea di Bulk Storage terhadap Kadar Ammoniak Bebas pada PT Pupuk Iskandar Muda. Tugas Akhir. Medan: Program Studi D3 Kimia Industri Departemen Kimia Fakultas Matematika dan Ilmu Pengetahuan Alam Universitas Sumatera Utara.

[15] Sundari, D. dkk. (2015). Analisis Amonia Terlarut pada Tanaman Lamun (Thalasia testudinum) dalam Media Air. Jurnal Kimia Mulawarman 12. No. 2. Hal 64 - 67.

[16] Said N.I. dan Sya'bani M.R. (2014). Penghilangan Amoniak di Dalam Air Limbah Domestik dengan Proses Moving Bed Biofilm Reactor (MBBR). JAI 7. No. 1. Hal $44-65$.

[17] Nevin, J.M. dan Lovatt C.J. (1987), Demonstration of Ammonia Accumulation and Toxicity in Avocado Leaves during WaterDeficit Stress, Proceeding. California: Department of Botany and Plant Sciences Universitas of California.

[18] Maulana, S., Dharmawan, M. R., Pratiwi, W. N., \& Yuwindry, I. (2020). Narrative Review: Ekstrak Daun Bangkal (Nauclea subdita. Merr) Terhadap Paru-Paru Hewan Uji yang Terpapar Polusi Udara Akibat Kebakaran Hutan. Journal of Pharmaceutical Care and Sciences, 1(1), 62-69.

[19] Halizah, N., Zahro, H. Z., \& Rudhistiar, D. (2021). Rancang Bangun Sistem Monitoring Polusi Udara Pada Budidaya Tanaman Sayur Hidroponik. JATI (Jurnal Mahasiswa Teknik Informatika), 5(1), 308-314.

[20]Bidweg, R.G.S. (1979). Plant Physiology. London: Coller Macmillan Publisher. 
[21] Raksun, A., Ilhamdi, M. L., wayan Merta, I., \& Mertha, I. G. (2021). The Effect of vermicompost and NPK fertilizer on tomato (Solanum lycopersicum) growth. Jurnal Pijar Mipa, 16(5), 688-694.

[22] Merta, I. W., \& Raksun, A. (2021). Growth response of pakcoy (Brassica rapa L.) due to difference dosage and time of giving bokashi. Jurnal Pijar Mipa, 16(4), 542-546.

[23] Raksun, A., \& Japa, L. (2019). Pengaruh Bokashi dan Pupuk NPK terhadap Pertumbuhan dan Hasil Kacang panjang. Pijar MIPA, 20(20), 8-11.

[24] Windiyati, E. dan Anwar, E.K. (2013). Pengujian Efektifitas Pupuk Hayati PH-E terhadap Pertumbuhan dan Hasil Tanaman Cabai. Laporan Penelitian. Bogor: Balai Penelitian Tanah Bogor. 